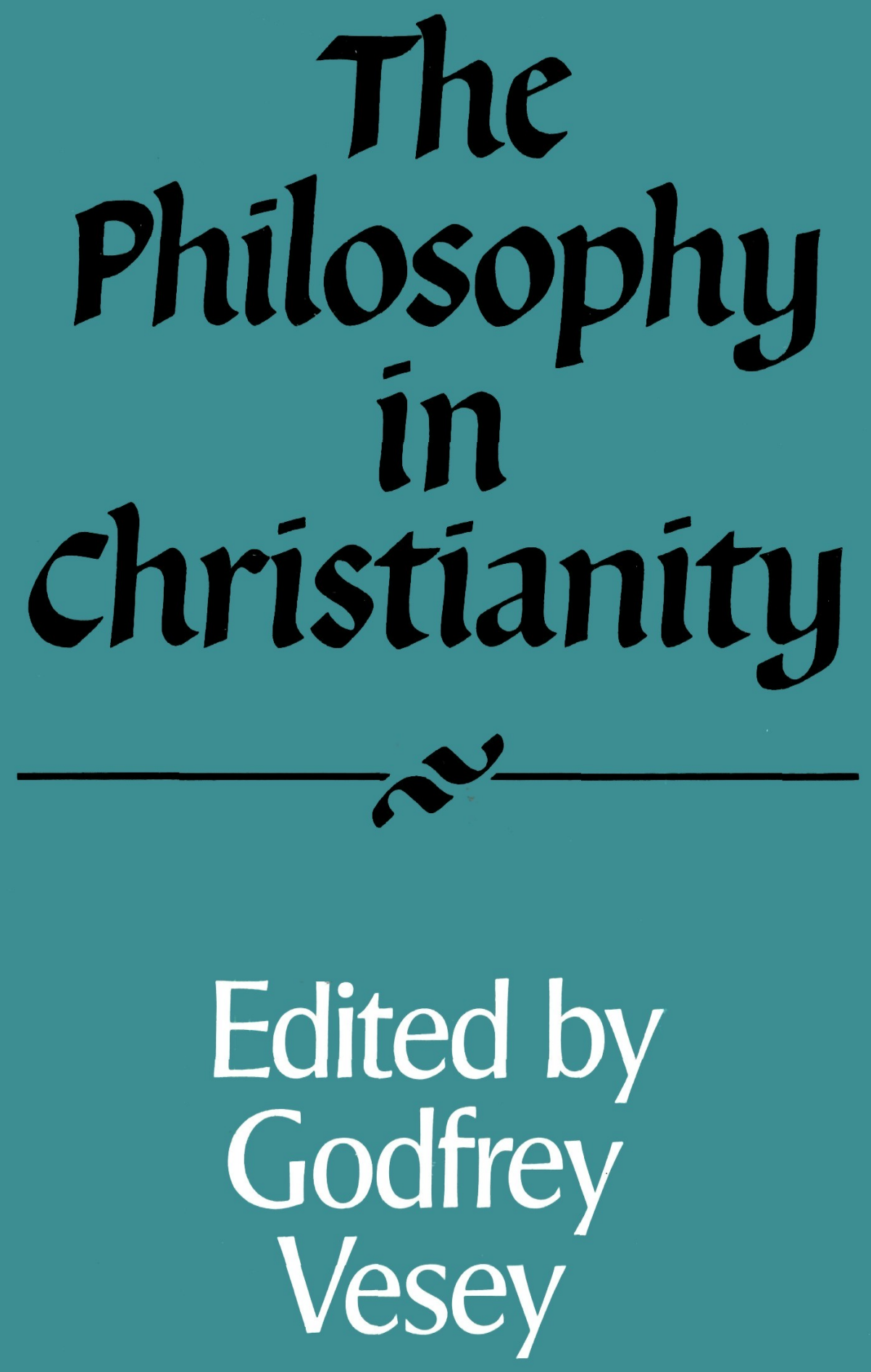




\section{The Philosophy in}

Christianity

EDITED BY

\section{Godfrey Vesey}

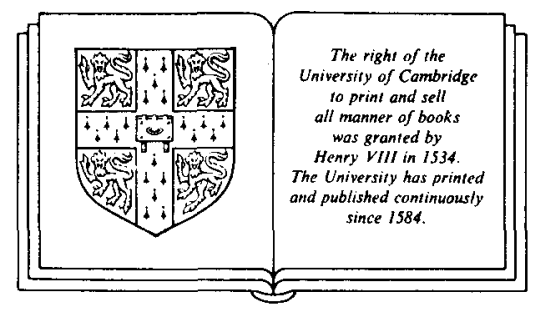

\section{CAMBRIDGE UNIVERSITY PRESS}

\section{CAMBRIDGE}

NEW YORK PORT CHESTER MELBOURNE SYDNEY 
Published by the Press Syndicate of the Lniversity of Cambridge The Pitt Building, Trumpington Street, Cambridge, CB2 1RP 40 West 20th Street, New York, NY 10011, LSA

10 Stamford Road, Oakleigh, Melbourne 3166, Australia

(C) The Royal Institute of Philosophy 1989

\section{British Library Cataloguing in Publication Data}

Vesey, Godfrey

Philosophy in Christianity.

1. Christian theology. Influence of European philosophy

I. Title

$230^{\prime} .01$

ISBN 0521375789 (paperback)

\section{Library of Congress Cataloguing in Publication Data}

Philosophy in Christianity/edited by Godfrey Vesev, p. cm. - (Royal Institute of Philosophy lecture serics : 25) ISBN 0521375789

1. Philosophy and religion - History of doctrines.

2. Christianity - Philosophy - I Iistory of doctrines.

I. Vesey, Godfrey Norman Agmondisham. II. Series:

Royal Institute of Philosophy lectures: v. 25.

BR100, P537 1989

$261.6^{\prime} 1-\mathrm{de} 20$ 


\section{Contents}

Foreword v v

GODFREY VESEY

Logos and Trinity: Patterns of Platonist Influence on Early 1

Christianity

JOHN DILLON

Reason in Mystery

NORMAN KRETZMANN

The Philosophy in Christianity: Arius and Athanasius MAURICE WILES

Could God Become Man?

RICHARD SWINBURNE

Augustine's Philosophy of Being

CHRISTOPHER STEAD

Predestination and Freedom in Augustine's Ethics GERARD O'DALY

God as Creator KEITH WARD

Foreknowledge and the Vulnerability of God

J. R. LUCAS

On Not Knowing too Much About God

A. H. ARMSTRONG

'Where Two Are to Become One': Mysticism and Monism GRACE JANTZEN

Faith and Goodness

ELEONORE STUMP

Hope

STEWAR'T SUTHERLAND

Christian Averroism, Fideism and the 'Two-fold Truth' 207 STUART BROWN

Does Philosophy 'Leave Everything as it is'? Even Theology? RENFORD BAMBROUGH

Chronological Chart

Index of Names

Index of Subjects 